\title{
Reengineering the Romanian Timber Supply Chain from a Process Management Perspective
}

\author{
Peter Rauch, Stelian Alexandru Borz
}

\begin{abstract}
Implementation of process management in the forest supply chains has a great potential for organizational and managerial improvement, at least by resource saving. Nevertheless, techniques of process management have been scarcely used to improve the forest supply chains in many parts of the world. In this study, for both Romanian state and private forests, the processes of the timber supply chain - from the harvest site to the forest-based industry plant-are mapped and analyzed. The main objectives of this work were to identify process optimization potentials and to redesign processes in order to improve the performance of the Romanian timber supply chain. Results show that particularly inter-organizational processes offer great saving potentials, mainly due to the existing multi-level hierarchy and multi-level control obligations. Therefore, introducing a web-based platform to enhance a collaborative workflow can considerably decrease the time needed for providing harvest sites or logs to customers via auctions. Further process optimization can be reached by the empowerment of lower level hierarchies facilitating the reduction of hierarchy levels of involved state organizations.
\end{abstract}

Keywords: timber supply chain, improvement options, potential, state forests, private forests, management, Romania, Business Process Model

\section{Introduction}

Since the introduction of the value chain concept by Porter (1980) and Business Process Reengineering (BPR) by Hammer and Champy (1993), process orientation has been seen as a key factor for business success. To identify competitive advantage, Porter (1985) suggests analyzing important strategic activities of the enterprise, denoted as a value chain. Each enterprise can be seen as an aggregation of activities for designing, producing, selling, consigning and supporting its product. The value chain of an enterprise is also part of a value system, which includes the value chains of suppliers and customers. Porter's value chain concept replaced functional fragmented analysis with processorientated analysis and laid the foundation for Business Process Management. Many different and quite synonymous terms are used for this approach such as process innovation, business process redesign, business reengineering or process engineering. Hammer and Champy (1993) define BPR as the »fundamental rethinking and the redesign of business processes to achieve dramatic improvements in critical, contemporary measures of performance, such as cost, quality, service and speed «. Aligning processes to meet customers' needs as well as defining customer requirements are seen as the main tasks of BPR. Optimized processes are usually achieved by eliminating duplicated tasks or repeated information and by redefining roles and responsibilities (McKay and Radnor 1998). Additionally, BPR »removes non-value added activities from processes, improves our cycle-time response capabilities and lowers process costs « (Ashayeri and Keij 1998), whereas continuous process improvement means to redesign processes only within a single functional activity, offering more incremental improvement potentials.

Process management potential in forestry is still under-investigated, at least in regards to country specificity in terms of legal, forest management and 
economic context, with just few studies reporting on process management applications in wood supply chains (e.g. Skutin 1996, Rauch 2003) or for a single business process in forestry (e.g. Erni et al. 2002, Oswald et al. 2004). Nevertheless, process management is seen as a promising tool in forestry and forest-based industry (Warkotsch and Ziesak 1998, Heinimann 2000). Introducing the concept of BPR to forest owner cooperations in Austria, Rauch (2005) found evidence for high potentials in optimizing processes in the wood supply chain. In particular, inter-organizational process interfaces offered high saving potentials in terms of money and time. One example was the exchange of wood measurement data from mills with forest owner cooperations (FOCs). Digital data was sent in an analog format and later re-digitalized in order to bridge different data format requirements. While external process supervision is fairly common in many industries, BPR was found to encounter resistance in forestry, being rather a new technique in this industry. Starting with a process-oriented approach, how to redesign organizational structures or develop new business models is a common challenge. Accordingly, for FOCs, Heinimann (1998, 1999) suggested the development of organization forms where small-scale forests are merged to forest production units and managed jointly. Based on process analyses of German and Austrian FOCs, process efficiency was compared for three different business process models. Due to lacking data on time spent by process owners on different processes, efficiency was indicated by process interactions. It was shown that reducing the number of interactions contributes to minimizing transaction costs of timber supply (Rauch and Gronalt 2005). Business process mapping methodology was applied to forest biomass supply chains in Finland and Germany to identify the business processes and it revealed that the number of processes varies considerably between Finnish and German supply chains (Windisch et al. 2013). In order to improve the production system for teak seedlings in Indonesia, Alkaff et al. (2017) applied BPR methods and deducted several reengineering measures. To determine the wood mobilization options for private forests in Serbia and Slovenia, different private forest owner organization models were proposed mainly based on business process analysis of processes like timber sales, harvesting, transportation and invoicing (Malovrh et al. 2017).

In many ways, the Romanian timber value chain differs from that of Western European countries. This is mainly due to the silvicultural options used, timber selling procedures and their associated issues (Fornea et al. 2018), market conditions, level of technology used in operations (Moskalik et al. 2017) and the stake- holders' organizational setup, which involves a wide range of organizations and interactions among them on the timber path from forest to final user, resulting in an excessive bureaucracy (Rauch et al. 2015).

The main goals of this study were to identify process optimization potentials and redesign processes. Romanian processes of the timber supply chain are analyzed and mapped, concentrating on order-to-delivery processes. Based on the analysis results, reengineering approaches are proposed to reduce the number of interactions among the process owners and to improve the effectiveness of the timber supply chain.

\section{Materials and Methods}

\subsection{The Romanian Timber Supply Chain}

Romanian forests cover more than 6.5 million hectares, spreading across more than $27 \%$ of the country's territory. Roughly half of the forest area is owned by the state and managed by the National Forest Administration, RNP Romsilva, under policy and legislative direction of the Forestry Department of the Ministry of Environment, Waters and Forests (Ministry). The remaining half is private property. Timber removals represent only $46 \%$ of the total growing stock increment (Abrudan et al. 2015). The annual harvested volume is low mainly due to the low accessibility of forest stands with an average density of forest roads of only $6.5 \mathrm{~m} /$ ha (Olteanu 2008), which contributes, among other factors, to a technical limitation in use of efficient harvesting technology (e.g. Apafaian et al. 2017, Borz et al. 2014a).

In Romania, the forest-based management activity is implemented by specific administrative organizations. There are roughly 480 such organizations including forest districts (FDs). Romsilva coordinates 42 county forest administrations (CFA) corresponding to the administrative counties of the country (Abrudan et al. 2015). Within all counties, there are 326 state forest districts (SFDs) under the administration of Romsilva and roughly 140 private forest districts (PFDs) (Abrudan et al. 2015, Marinchescu et al. 2013). A PFD has roughly the same organizational structure as a SFD. The number of employees varies depending on the FD size and the number of its departments. Within a forest district, the forest is divided into management units (MUs), which are normally delimited in natural catchment areas varying from 1000 to 5000 ha. Forest management plans (FMPs) contain operational prescriptions and are regularly prepared for each $\mathrm{MU}$, having typically a 10 -year validity (Abrudan 2012). The main purpose of a FMP is to plan, guard and account for forest-based 
services and products including timber and non-timber forest products (NTFPs). Forest management is done based on the prescriptions of FMPs. In general, public forests are managed by Romsilva, whereas the private forests are mainly managed by PFDs. For private forest owners, the forest management planning is mainly done by private companies and for state forests, by the National Forestry Research and Development Institute (NFRDI), which was formerly known as the Forestry Research and Management Planning Institute, ICAS. In both cases, the FMPs undergo authorization by the Ministry. Both, private and state forests districts are subject to controls carried out by the Forest Guard (FG), the former County Forest Inspectorate (CFI). FG is a public organization exclusively financed by the Romanian State Budget directly subordinated to the Ministry. Its core function is to represent the Ministry in the territory by attributions of control and implementation. It is divided into nine territorial branches that control the implementation of forestry activities for most of the actors within the supply chain.

Irrespective of ownership type, the main harvesting method is tree-length as a trade-off between the existing wood harvesting technology, available infrastructure

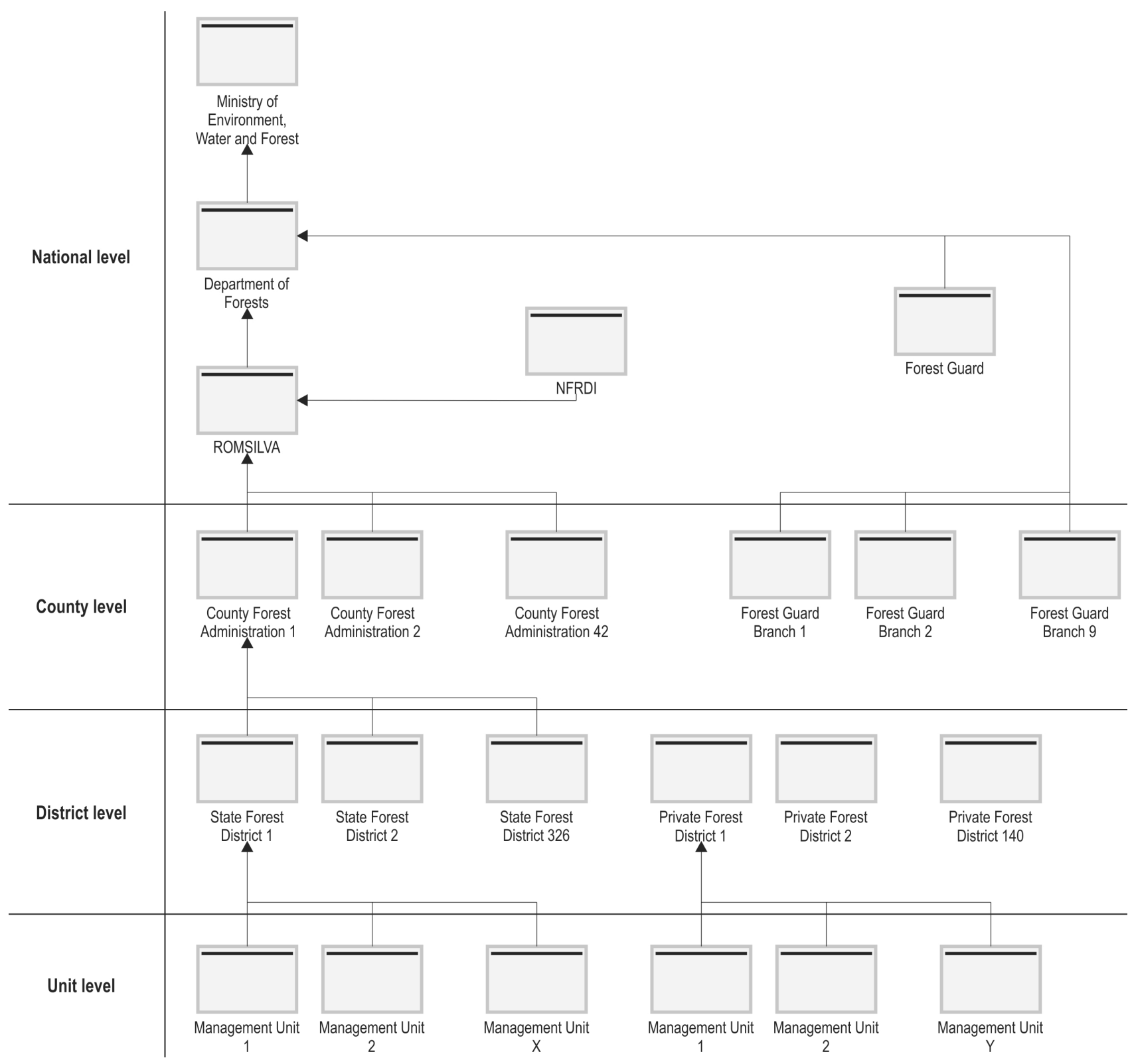

Fig. 1 Organization chart of timber supply chain 
and harvesting performance (Oprea 2008). The prevailing harvesting system combines motor-manual tree felling and processing with extraction done by winch skidders (e.g. Borz et al. 2013, Borz et al. 2014b, Borz et al. 2015, Ignea et al. 2017, Moskalik et al. 2017). In this operational configuration, final wood assortments are usually bucked at the road side and then transported by trucks to intermediate storage facilities, to forest-based industry plants or to private households. In 2016, more than 4700 companies were authorized for wood harvesting and processing activities (www.mmediu.ro). Via public auctions, Romsilva sells standing timber or logs delivered at roadside or intermediate storage facilities (e.g. Fornea et al. 2018).

In regards to the efficiency of controls to avoid illegal logging, there are some implemented measures in addition to the controls of the FG as well as the application of corrective actions. One measure, which depends on civic duty of the society, is the use of the national emergency number (112) to report any suspicious wood transport. This system is open to the public 24 hours a day, seven days a week. Such calls automatically trigger a control on the documents of the respective wood transport. Moreover, the recently integrated informational system for tracking wood materials (SUMAL) was put in place in order to monitor the wood flow from harvest site to final destination. The person owning the delivery note is obliged to enter standard information such as assortment, species, volume and place of harvest into SUMAL via smartphone/tablet (offline if in the forest and no signal is available and then later online), which automatically generates a unique code to be written on the delivery note. In many ways, the underlying concept of this system is similar to that described by Figorilli et al. (2018), as well as to other proprietary systems developed by some Romanian companies.

\subsection{Process Management}

Various models for BPR projects are available, mainly consisting of three to eleven stages, however, most pursue a similar path and share commonalities in key areas (Vakola and Rezgui 2000). The BPR project model applied here is composed of three stages:

$\Rightarrow$ identify the process to be re-engineered

$\Rightarrow$ model (map) the processes

$\Rightarrow$ improve the processes (cf. Barber et al. 2003).

The basis of the process model development is the specific process chain definition. In this case, the starting point is the harvesting or wood procurement planning activities in Romanian state or private forests for their business customers. The end point is marked by the receipt of payment. The material and information flow of the order-to-delivery process is investigated as knowledge of those individual processes and their inplant functions are required for redesigning the supply chain in part or as a whole. Furthermore, a detailed process analysis records interfaces between data exchange and planning data.

The instrument to gain knowledge of intra- and inter-organizational processes is called process analysis. One task of process analysis is to completely cover and document the main order and logistic chain (Gudehus 1999). Additionally, it provides profound knowledge and transparency of actual processes and interfaces (Schwegmann and Laske 2002) and is a fundamental basis for redesigning efforts (Kuhn and Hellingrath 2002). In many cases, processes of enterprises connected in a specific supply chain are not standardized or jointly coordinated. Therefore, knowing processes and their diverse functions, which was the backbone of this study, is the basic requirement before starting to design new processes or process models. Accordingly, »it is even more important to understand existing processes before designing new ones « (Vakola and Rezgui 2000). Even within a company, the lack of transparency of business processes is an important problem since decisions affecting processes are based on a weak information base (Schuderer 1996).

A connected and completed sequence of activities fulfilling a business function is called a business process and consists of a flow and transformation of material, information, operations, and decisions (Staud 2001). In other words, a business process comprehends a structured sequence of cross functional activities and features a start and a finish as well as an input and an output (Osterloh and Frost 2003). Furthermore, organizational processes can be defined as follows: $\gg$ A process is simply a structured set of activities designed to produce a specific output for a particular customer or market. It has a beginning, an end, and clearly identified inputs and outputs. A process is therefore a structure for action, for how work is done« (Davenport 1994). Business processes management aims at adapting the supply chain according to a changing environment as well as at optimizing existing processes (Rauch and Gronalt 2005). Various tools are available for mapping business processes. This study uses the Adonis business management toolkit (BOC 2017), mainly due to its capabilities to deal with the studied problem and freeware availability. Based on an extensive documentation in the field and at the office, and several pre-analysis stages, processes are mapped 
with the help of two modelling layers providing different aggregation levels: process map and business process model. The first reflects the process architecture, addresses top management and provides an overview of the core processes. Decomposing the core processes leads to a detailed business process model that is the basis for re-engineering and facilitates identification of redundancies or process locks and loops (McKay and Radnor 1998).

\section{Results}

\subsection{Process Architecture of the Romanian Timber Supply Chain}

Fig. 2 shows the process map providing an overview of the timber supply chain from Romanian forests to mill. Processes indicated by the process map can be defined as follows:

$\Rightarrow$ Forest Management Planning: Every 10 years, NFRDI and private companies set up a new forest management plan, which includes volumes to be harvested and other silvicultural measures for state and private forests. The measures are performed at forest compartment and management unit levels

$\Rightarrow$ Lots preparation: Based on the forest management plan, SFD and PFD prepare forest lots for auctions. This comprises, but is not limited to, field operations such as tree marking, calculating harvest volumes and preparing required documents

$\Rightarrow$ Harvest Auctions: Descriptive data of the lots to be sold is posted online. Prerequisites for participation are documents for the authorization to harvest timber, a clearance certificate and a warranty deposit. After winning an auction, the agent signs a contract with the CFA and pays a deposit before receiving the authorization to start

$\Rightarrow$ Harvesting Process: Lots are sold as standing timber and harvested by authorized logging companies. Lots not sold at auction will be harvested and sold via auction by the SFD or PFD. In such cases, timber is usually harvested by authorized logging companies based on a service contract

$\Rightarrow$ Transport: Timber is transported mainly by trucks, which can be owned by logging companies, NFA or by independent carriers

$\Rightarrow$ Reception at the mill: Based on agreement, the forest-based industry sends a delegate to the forest to measure logs, while loading the truck or logs are measured at the mill yard.

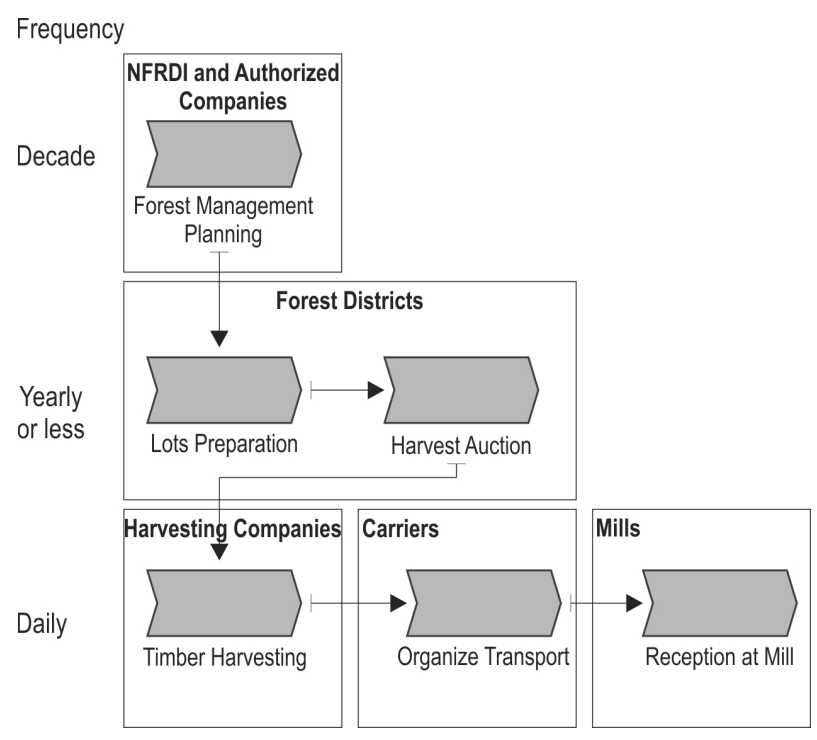

Fig. 2 Process Map (NFRDI - National Forestry Research and Development Institute)

\subsection{Business Process Model of the Romanian Timber Supply Chain}

The business process model reflects the actual status of the supply chain in detail and includes actors of the wood supply chain from forest to mill (Fig. 3). These are the contract (FD carrier), harvesting contractor, forest district (FD), director of forest district (FD Dir), county forest administration (CFA), director of county forest administration (CFA Dir), forest guard (FG) and the chief inspector of forest guard (FG CI). The business process model of the Romanian timber supply chain was mapped based on face-to-face interviews, e-mail and telephone communication, expert workshops and available literature.

\subsection{Process Analysis}

\subsubsection{Intra-Organizational Processes}

Intra-organizational processes are mainly characterized by a high degree of bureaucracy, various levels

Table 1 Interactions between specific administrative organizations of the Romanian timber supply chain

\begin{tabular}{|l|c|c|c|c|c|c|}
\hline Organization & FD Dir & CFA & CFA Dir & FG & FG Cl & Total \\
\hline FD & 3 & 2 & 1 & 4 & 1 & 11 \\
\hline FD Dir & - & 0 & 0 & 0 & 0 & 3 \\
\hline CFA & - & - & 1 & 0 & 0 & 3 \\
\hline CFA Dir & - & - & - & 0 & 0 & 2 \\
\hline FG & - & - & - & - & 1 & 5 \\
\hline
\end{tabular}




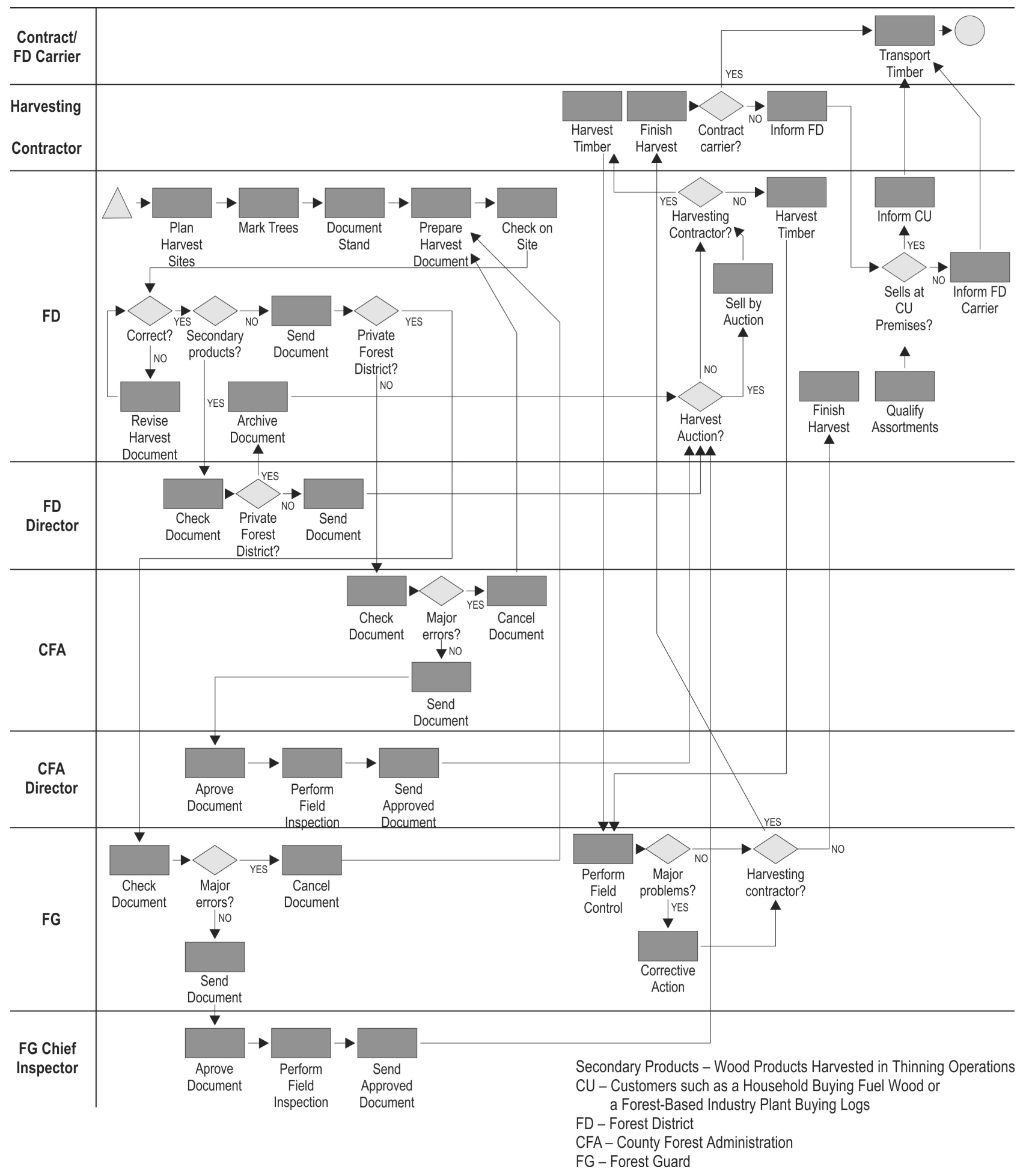

Fig. 3 Business process model

of internal control and lack of a digital system to support the workflow between the hierarchical levels involved in the entire process. For instance, some of the harvesting documentation is sent for control first to the
CFA and then to the FG (the independent control body). Meanwhile, the forest district employee has no feedback on the status of the approval and, in case of any errors detected, documents are returned for resubmission. 
Bureaucracy of intra-organizational processes can also be seen by the high number of interactions between the specific organizational units that are needed to manage a business case (here a single timber sale) as well as the number of involved units (Table 1).

\subsubsection{Information Exchange Weakness}

The main weakness of the actual business process model is that information exchange is done primarily in an analog format, i.e. many of the documents circulating between the hierarchical levels are in print format and sent via ground mail. This procedure is time consuming and also shows further drawbacks of analog data transfer. Each hierarchical level requires a mail office or something similar that records in- and outgoing mail and distributes documents to the corresponding units. Furthermore, analog data does not support automated checks of input data. Consequently, errors made by a pre-processing unit can result in delays and the need to return documents back to the pre-processing unit for redistribution. Additionally, much of the data processed by the hierarchical levels in order to set up harvesting auctions have to be digitalized at a later stage to provide information on the harvesting lots of an auction. Therefore, the lack of a modern information system to support operations and communication between the institutions involved (SFD, PFD, CFA and FG) is seen as a major information exchange limitation.

\subsection{Business Process Redesign - Improvement of Processes}

Developing innovative cooperation procedures and smart processes are the main redesigning tasks. Important criteria for selecting processes for redesign are core competence, potential (in terms of cost or time savings) and capability of processes to be standardized. According to business process analyses, information exchange and internal communication primarily have to be addressed by the redesign task. The whole timber supply process has to be investigated with special attention given to the legal framework, legally defined competences of different forest authorities and the legally binding process of how to sell wood in Romania. Therefore, the proposed redesign will not provide an organizational redesign in terms of minimizing hierarchical levels by means of empowerment since implementation of such a redesign would require major amendments to the Romanian Forest Law.

The central idea is to implement a platform that digitally connects the main actors of the timber supply chain in a workflow system. The platform should provide access to three different user groups: two internal users and one public user group, i.e. mainly the wood buyers, but can also be extended to the interested members of public society. The first internal user group is the organizational unit SFD or PFD, which prepares the digital harvesting documents. This process includes field evaluation, data input, type of forest administrator and scheduled cuts. After the relevant data is provided and automatically cross-checked for typos, logical errors and basic fit to the forest management plan, the harvesting document is generated. All harvesting documents from one FD will be analyzed, mainly focusing on harvesting volumes and forest sites, and approved by the unit manager. Then, according to the provided information, the system automatically distributes the digital harvesting document for further processing.

The second internal user group are the control institutions. After receiving notification, the responsible clerk verifies if the harvesting document is in compliance with respective legal term, releases it for director approval or rejects an incorrect document, which will be returned for recheck to the SFD or PFD. If a document raises suspicion or is randomly selected, the control institution can perform field inspections. After the director digitally validates the documents by electronic signature, final approval is forwarded to the respective FD, which then can set up an auction to sell standing timber or start the harvest and set up an auction for harvested logs. For an auction, the FD publishes the harvesting documents online. Potential participants register via the platform, upload the necessary documents for participation (e.g., participation deposit payment receipt and technical documents) and place an offer. After the auction deadline, a clerk verifies the documents for each participant and selects the winning bid. Automatically, the system generates a contract draft, which is sent via the platform to the winning participant for signature. The other participants are notified of the result by a standardized message sent by the system. The winning participant uploads a scanned copy of the signed contract including relevant legal forms and can start harvesting operations. If harvesting sites are not sold, FD decides whether to subcontract harvesting services and sell the logs at a subsequent auction or to postpone the harvest.

\section{Discussion and Conclusion}

Mapping the actual business processes of the Romanian timber supply chain provided the basis for identifying the main weaknesses of insufficient electronic data processing support and set the stage for redesign to make processes faster, cheaper or smoother. The 
purpose of the reengineering effort is to eliminate nonefficient processes in order to free up qualified personnel for more added value work. Therefore, introducing a web-based platform enhancing a collaborative workflow and automatic corrections of typos and logical flaws will reduce wait time caused by ground disbursement of documents, eliminate in- and outgoing mail services and decrease the number of documents requiring correction, return and redistribution. The redesigned process will dramatically decrease the time needed for providing harvesting sites to the customers via auctions as ground distribution and analog document exchange between the hierarchical levels will be completely eliminated; this is important since the reduction in terms of number of interactions (Rauch and Gronalt 2005) and especially in terms of face-to-face interactions have been proved to have the potential for saving. Of course, the introduction of a web-based platform would require, right at the beginning, an investment in both technology and training. Nevertheless, the benefits that could be achieved in terms of efficiency increment will compensate in a very short term the technology development and training costs.

Further improvement potential lies in the introduction of a standardized supply chain management application that provides a link and data distribution channel between the different actors of the supply chain like Romsilva, forest entrepreneurs, haulage contractors and customers. Windisch et al. (2010) show that such tools successfully improve efficiency and profitability of forest fuel procurement.

Another process optimization potential lies in the redesign of the actual hierarchical structure of Romsilva. In particular, streamlining the organizational structure by, for example, empowerment measures providing district or unit level managers with more decisionmaking power shows potential. Organizational change can be made in an evolutionary way, reflecting on experience and knowledge of personnel and involving staff, a procedure that leads more often to cooperation and sustainable change. It is seen as a first step to introduce business process management and as a promising start of a change process that will be at least co-driven by the involved staff. Also, by transferring decision making to lower hierarchical levels, the top managers could focus more on business development given the fact that CFAs, for instance, manage diverse product and service supply chains related to forests and forestry.

Applying a process-orientated value chain concept revealed potentials to optimize processes in the Romanian timber supply chain. Particularly, inter-organizational processes, due to the actual existing multi-level hierarchy and multi-level control obligations, show great potentials for saving time and money by means of rethinking hierarchical levels and empowering lower level hierarchies.

\section{References}

Abrudan, I.V., 2012: A decade of non-state administration of forests in Romania: achievements and challenges. Int. For. Rev. 14(3): 275-284. https://doi.org/10.1505/146554812802646684

Abrudan, I.V., Popa, B., Văcălie, C., Hălălişan, A.F., 2015: Forestland restitution laws in post-communist Romania. In Proceedings of the $16^{\text {th }}$ International Symposium on Legal Aspects of European Forest Sustainable Development, Brașov, Romania, 20-22 May. Transilvania University Press, Brașov, Romania 77-86 p.

Alkaff, M., Marimin, M., Arkeman, Y., Sukardi, S., Purnomo, H., 2017: Business Process Reengineering of Sustainable Teak Forest at Agroforestry Industry. IRJBS 9(3): 169-183.

Apafaian, A.I., Proto, A.R., Borz, S.A., 2017: Performance of a mid-sized harvester-forwarder system in integrated harvesting of sawmill, pulpwood and firewood. Ann. For. Res. 60(2): 227-241. https://doi.org/10.15287/afr.2017.909

Ashayeri, J., Keij, R., 1998: Global business process re-engineering: a system dynamics-based approach. Int. J. Oper. Prod. Manag. 18(9/10): 817-831. https://doi. org/10.1108/01443579810225478

Barber, K.D., Dewhurst, F.W., Burns, R.L.D.H., Rogers, J.B.B., 2003: Business-process modelling and simulation for manufacturing management: A practical way forward. BOMJ 9(4): 527-542. https://doi.org/10.1108/14637150310484544

BOC Group, 2017: The Business Process Management Toolkit ADONIS. Strengths and application scenarios $56 \mathrm{p}$. Available online: https://uk.boc-group.com/uploads/files/_2015_ ADONIS_Whitepaper_-_EN_12.pdf

Borz, S.A., Dinulica, F., Birda, M., Ignea, G., Ciobanu, V.D., Popa, B., 2013: Time Consumption and Productivity of Skidding Silver Fir (Abies alba Mill.) Round Wood in Reduced Accessibility Conditions. Ann. For. Res. 56(2): 363-375.

Borz, S.A., Birda, M., Ignea, G., Popa, B., Campu, V.R., Iordache, E., Derczeni, R.A., 2014a: Efficiency of a Woody 60 Processor Attached to a Mounty 4100 Tower Yarder when Processing Coniferous Timber from Thinning Operations. Ann. For. Res. 57(2): 333-345.

Borz, S.A., Ignea, G., Popa, B., 2014b: Modelling and Comparing Timber Winching Performance in Windthrow and Uniform Selective Cuttings for Two Romanian Skidders. J. For. Res. 19(6): 473-482. https://doi.org/10.1007/s10310-014-0439-0

Borz, S.A., Ignea, G., Popa, B., Sparchez, G., Iordache, E., 2015: Estimating Time Consumption and Productivity of Roundwood Skidding in Group Shelterwood System - a Case Study in a Broad Leaved Mixed Stand Located in Reduced Accessibility Conditions. Croat. J. For. Eng. 36(1): 137-146.

Davenport T.H., 1994: Managing in the new world of process. PPMR 18(2): 133-147. https://doi.org/10.2307/3380643 
Erni, V., Lemm, R., Frutig, F., Oswald, K., 2002: Abbildung von Prozessketten mit Componentware, dargestellt am Beispiel Holzernte. Modelling of process chains with component-ware; the example of timber harvesting. Schweiz. Z. Forstwes. 153(12): 462-470.

Figorilli, S., Antonucci, F., Costa, C., Pallottino, F., Raso, L., Castiglione, M., Pinci, E., Del Vecchio, D., Colle, G., Proto, A.R., Sperandio, G., Menesatti, P., 2018: A Block Implementation Prototype for the Electronic Open Source Traceability of Wood along the Whole Supply Chain. Sensors 18(9): 3133. https://doi.org/10.3390/s18093133.

Fornea, M., Birda, M., Borz, S.A., Popa, B., Tomašić, Ž., 2018: Harvesting conditions, market particularities or just economic competition: a Romanian case study regarding the evolution of standing timber contracting rates. Sumar. list 142(9-10): 499-508. https://doi.org/10.31298/sl.142.9-10.5.

Gudehus, T., 1999: Logistik: Grundlagen, Strategien, Anwendungen; Springer Verlag: Berlin, Heidelberg, Deutschland; 891 p.

Hammer, M., Champy, J., 1993: Reengineering the corporation: A Manifesto for Business Revolution; Harper Collins Publishers, New York, USA, 223 p.

Heinimann, H.R., 1998: Betrieb und Produktion in der Forstwirtschaft der Zukunft. Eidgenössische Forschungsanstalt für Wald, Schnee und Landschaft (Hrsg.), Optimierung der Produktionskette Holz, Forum für Wissen: 71-78.

Heinimann, H.R., 1999: Logistik der Holzproduktion - Stand und Entwicklungsperspektiven. Forstw. Cbl. 118: 24-38. https://doi.org/10.1007/BF02768971

Heinimann, H.R., 2000: Business Process Re-engineering - a Framework for Designing Logistics Systems for Wood Procurement. In Proceedings of the $1^{\text {st }}$ World Symposium on Logistics in the Forest Sector, Helsinki, Finland, May 15-16: Eds. Sjöström; Timber Logistics Club, Helsinki, Finland: 269-287.

Ignea, G., Ghaffaryian, M.R., Borz, S.A., 2017: Impact of Operational Factors on Fossil Energy Inputs in Motor-Manual Tree Felling and Processing. Ann. For. Res. 60(1): 161-172. https://doi.org/10.15287/afr.2016.705

Kuhn, A., Hellingrath, B., 2002: Optimierte Zusammenarbeit in der Wertschöpfungskette; Springer Verlag: Berlin, Heidelberg, Deutschland; 286.

Marinchescu, M., Halalisan, A.F., Popa, B., Abrudan, A.I., 2014: Forest Administration in Romania: Frequent Problems and Expectations. Not. Bot. Horti. Agrobo. 42(2): 588-595. https://doi.org/10.1583/nbha4229738

Moskalik, T., Borz, S.A., Dvorak, J., Ferencik, M., Glushkov, S., Muiste, P., Lazdins, A., Styranivsky, O., 2017: Timber Harvesting Methods in Eastern European Countries: A Review. Croat. J. For. Eng. 38(2): 231-241.

Olteanu, N., 2008: Drumuri forestiere. Volumul I - Proiectarea drumurilor forestiere. Rețele de drumuri forestiere [Eng. Forest Roads. Volume I - Forest road design. Forest roads network]. Transilvania University Press, Brașov, Romania; 339 p.
Oprea, I., 2008: Tehnologia exploatării lemnului [Eng. Timber Harvesting Technology]. Transilvania University Press, Braşov, Romania; 273 p.

Osterloh, M., Frost, J., 2003: Prozessmanagement als Kernkompetenz: Wie Sie Business Reengineering strategisch nutzen können, $4^{\text {th }}$ ed; Gabler Verlag: Wiesbaden, Deutschland; $282 \mathrm{p}$.

Oswald, K., Riechsteiner, D., Thees, O., Lemm, R., 2004: Reorganisation of Wood Production for Improved Performance: a Swiss Forest District Case Study. Small-scale For. Econ. Manage. Policy 3(2): 143-160. https://doi.org/10.1007/s11842004-0011-4

Malovrh, Š.P., Kumer, P., Glavonjić, P., Nonić, D., Nedeljković, J., Kisin, B., Avdibegović, M., 2017: Different Organizational Models of Private Forest Owners as a Possibility to Increase Wood Mobilization in Slovenia and Serbia. Croat. J. For. Eng. 38(1): 127-140.

McKay, A., Radnor, Z, 1998: A characterization of a business process. IJOPM 18(9/10): 924-936. https://doi.org/10.1108/ 01443579810225522

Porter, M.E., 1980: Competitive Strategy: Techniques for Analyzing Industries and Competitors. The Free Press, New York, USA, 432 p.

Porter, M.E., 1985: Competitive Advantage. Creating and sustaining superior performance. The Free Press, New York, USA, 557 p.

Rauch, P., 2003: Strategies and methods for an efficient management of small scale forests - SWOT analysis, process management, GIS-based analysis of harvesting potential and organisational development. PhD thesis, University of Natural Resources and Life Sciences, Vienna, $176 \mathrm{p}$.

Rauch, P., 2005: Business networking in the forest wood supply chain. Austrian J. For. Sci. 122(4): 185-204.

Rauch, P., Gronalt, M., 2005: Evaluating Organisational Designs in the Forestry Wood Supply Chain to Support Forest Owners Cooperations. Small-scale For. Econ. Manage. Policy 4(1): 53-68. https://doi.org/10.1007/s11842-005-0004-y

Rauch, P., Wolfsmayr, U.J., Borz, S.A., Triplat, M., Krajnc, N., Kolck, M., Oberwimmer, R., Ketikidis, C., Vasilijevic, A., Stauder, M., Muehlberg, C., Derczeni, R., Oravec, M., Krissakova, I., Handlos, M., 2015: SWOT analysis and strategy development for forest fuel supply chains in South East Europe. For. Pol. Econ. 61: 87-94. https://doi.org/10.1016/j.forpol.2015.09.003

Skutin, S.G., 1996: Business Process Improvement: The Key to Satisfied Customers and Cost Reduction. General Technical Report - North Central Forest Experiment Station, USDA Forest Service; NC-186: 260-268.

Schuderer, P., 1996: Prozeßorientierte Analyse und Rekonstruktion logistischer Systeme. Deutscher Universitätsverlag: Springer Fachmedien Wiesbaden, Deutschland; 333 p.

Schwegmann, A., Laske, M., 2002: Istmodellierung und Istanalyse. 147-178. https://doi.org/10.1007/978-3-662-223550_5. In: Prozessmanagement; Becker, J., Kugeler M., Rose- 


\section{P. Rauch and S.A. Borz Reengineering the Romanian Timber Supply Chain from a Process Management Perspective (85-94)}

mann M., Eds.; Springer: Berlin, Heidelberg, Deutschland; $628 \mathrm{p}$.

Staud, J.L., 2001: Geschäftsprozessanalyse: Ereignisgesteuerte Prozessketten und objektorientierte Geschäftsprozessmodellierung für Betriebswirtschaftliche Standardsoftware. Springer Verlag: Berlin, Heidelberg, Deutschland, 378 p.

Vakola, M., Rezgui, Y., 2000: Critique of existing business process re-engineering methodologies: The development and implementation of a new methodology. BPMJ 6(3): 238-250. https://doi.org/10.1108/14637150010325453.

Warkotsch, W., Ziesak, M., 1998: Die Holzerntekette - Probleme und Lösungsansätze. The timber supply chain - prob- lems and solutions. Schriftenreihe des Instituts für Forsttechnik, Band 8: 49-55.

Windisch, J., Sikanen, L., Röser, D., Gritten, D., 2010: Supply chain management applications for forest fuel procurement - cost or benefit? Silva Fenn. 44(5): 845-858. https://doi. org/10.14214/sf.124

Windisch, J., Röser, D., Mola-Yudego, B., Sikanen, L., Asikainen, A., 2013: Business process mapping and discreteevent simulation of two forest biomass supply chains. Biomass Bioenerg. 56: 370-381. https://doi.org/10.1016/j. biombioe.2013.05.022

www.mmediu.ro: last accessed on the 20.10.2016

(C) 2019 by the authors. Submitted for possible open access publication under the terms and conditions of the Creative Commons Attribution (CC BY) license (http://creativecommons.org/licenses/by/4.0/).

Received: December 10, 2018

Accepted: July 23, 2019
Authors' addresses:

Hon. prof. priv. doc. dr. Peter Rauch

e-mail: peter.rauch@boku.ac.at

University of Natural Resources and

Life Sciences, Vienna

Department of Economics and Social Siences

Feistmantelstrasse 4

1180, Wien

AUSTRIA

Prof. Stelian Alexandru Borz, PhD. *

e-mail: stelian.borz@unitbv.ro

Transilvania University of Braşov

Faculty of Silviculture and Forest Engineering

Department of Forest Engineering, Forest

Management Planning and Terrestrial Measurements

Şirul Beethoven No. 1

500123, Braşov

ROMANIA

* Corresponding author 